\title{
Plant-soil feedbacks in declining forests: implications for species coexistence
}

\author{
Lorena Gómez-Aparicio, ${ }^{1,3}$ Jara Domínguez-Begines, ${ }^{1}$ Paul Kardol, ${ }^{2}$ \\ José M. Ávila, ${ }^{1}$ Beatriz Ibáñez, ${ }^{1}$ And Luis V. García ${ }^{1}$ \\ ${ }^{1}$ Instituto de Recursos Naturales y Agrobiología de Sevilla (IRNAS), CSIC, PO Box 1052, Sevilla 41080 Spain \\ ${ }^{2}$ Department of Forest Ecology and Management, Swedish University of Agricultural Sciences, SE-901 83 Umeå, Sweden
}

\begin{abstract}
Plant-soil feedbacks (PSFs) play a relevant role as drivers of species abundance, coexistence, and succession in plant communities. However, the potential contribution of PSFs to community dynamics in changing forest ecosystems affected by global change drivers is still largely unexplored. We measured the direction, strength and nature (biological vs. chemical) of PSFs experienced by coexisting tree species in two types of declining Quercus suber forests of southwestern Spain (open woodland vs. closed forest) invaded by the exotic soil pathogen Phytophthora cinnamomi. To test PSFs in a realistic community context, we focused not only on individual PSFs (i.e., comparing the growth of a tree species on conspecific vs. heterospecific soil) but also calculated net-pairwise PSFs by comparing performance of coexisting tree species on their own and each other's soils. We hypothesized that the decline and death of Q. suber would alter the direction and strength of individual and net-pairwise PSFs due to the associated changes in soil nutrients and microbial communities, with implications for recruitment dynamics and species coexistence. In support of our hypothesis, we found that the decline of $Q$. suber translated into substantial alterations of individual and net-pairwise PSFs, which shifted from mostly neutral to significantly positive or negative, depending on the forest type. In both cases however the identified PSFs benefited other species more than $Q$. suber (i.e., heterospecific positive PSF in the open woodland, conspecific negative PSF in the closed forest). Our results supported PSFs driven by changes in chemical soil properties (mainly phosphorus) and arbuscular mycorrhizal fungi, but not in pathogen abundance. Overall, our study suggests that PSFs might reinforce the loss of dominance of $Q$. suber in declining forests invaded by $P$. cinnamomi by promoting the relative performance of non-declining coexisting species. More generally, our results indicate an increase in the strength of net PSFs as natural forests become disturbed by global change drivers (e.g., invasive species), suggesting an increasingly important role of PSFs in forest community dynamics in the near future.
\end{abstract}

Key words: arbuscular mycorrhizal fungi; context dependence; ectomycorrhizal fungi; forest decline, invasive species; root traits; soil-borne pathogens.

\section{INTRODUCTION}

The study of plant-soil feedbacks (PSFs) is an emerging area of research which has received much attention in the last two decades due to the increasingly recognized role of PSFs as drivers of plant species abundance, coexistence, diversity and community succession (Klironomos 2002, Ehrenfeld et al. 2005, Kulmatiski and Kardol 2008, Bever et al. 2010, Van der Putten et al. 2013, 2016, Teste et al. 2017). PSFs are considered to occur when a plant species modifies soil properties in a way that affects its own performance, either positively or negatively. Positive PSFs are suggested to increase plant abundance and persistence promoting competitive exclusion, whereas negative PSFs are considered to encourage species coexistence at local scales (Mangan et al. 2010a,

Manuscript received 22 September 2016; revised 14 February 2017; accepted 23 March 2017. Corresponding Editor: Christine V. Hawkes.

${ }^{3}$ E-mail: lorenag@irnase.csic.es
Mack and Bever 2014, Rutten et al. 2016) and contribute to successional species replacement at larger temporal scales (Van der Putten et al. 1993, Kardol et al. 2006, Bauer et al. 2015). To date, the majority of PSF studies have focused on temperate grassland and oldfield ecosystems, while less is known about the role of PSFs in forest systems (Kulmatiski et al. 2008, McCarthy-Neumann and Ibáñez 2013, Wurst et al. 2015, Rutten et al. 2016). Moreover, a meta-analysis by Kulmatiski et al. (2008) suggested that woody species tend to suffer less from feedbacks than herbaceous species, although the low sample size precluded strong conclusions. More research is clearly needed to improve our understanding of the role that PSFs play in the dynamics of forest ecosystems.

The analysis of PSFs in forest systems is particularly pertinent in the context of global change, where processes such as climate warming or invasive species are strongly altering the interactions among plants and soils (Bardgett and Wardle 2010, Van der Putten et al. 2016). A significant example is the exotic soil pathogen 
Phytophthora cinnamomi which causes severe decline of tree species in contrasting ecosystems worldwide from Australian jarrah (Eucalyptus marginata) forests (Weste and Marks 1987, Cahill et al. 2003) to European oak forests (Brasier 1992, Sánchez et al. 2006, Scanu et al. 2013). Phytophthora cinnamomi is considered one of the 100 most aggressive invasive species on earth (Lowe et al. 2004), and although considered a generalist pathogen, it often shows strong preference for certain species within mixed communities. For example, in Mediterranean oak forests of the Iberian Peninsula evergreen oak species (e.g., Quercus ilex, Quercus suber) are much more vulnerable to $P$. cinnamomi than coexisting deciduous oaks or other tree species, and suffer from high mortality rates that are severely changing forest structure (Moreira and Martins 2005, Camilo-Alves et al. 2013). However, the potential role of PSFs in tree species recruitment and coexistence in these changing forest communities remains unexplored.

In this paper, we sought to determine the direction and strength of PSFs experienced by coexisting tree species in declining $Q$. suber forests of southwestern Spain invaded by $P$. cinammomi, and to evaluate their role as drivers of species replacement or coexistence. Previous studies in these forests have shown that adult trees of different species and health status vary in their effects on soil chemistry (Aponte et al. 2011, Ávila et al. 2016) and the diversity and/or abundance of mycorrhizae (Aponte et al. 2011, 2013, Ibáñez et al. 2015) and soil pathogens (Gómez-Aparicio et al. 2012). However, it is unknown whether these shifts in chemical and biological soil properties affect seedling performance. To test this, we conducted a greenhouse experiment where seedlings of three tree species (Q. suber, Olea europaea, and Quercus canariensis) were grown in soil collected under adult trees of different species and health status from two sites representative of the main mixed $Q$. suber forest types of the region: a $Q$. suber-O. europaea open woodland and a $Q$. suber-Q. canariensis closed forest. Both forest types suffer from $Q$. suber decline driven by $P$. cinnamomi, but have contrasting soil characteristics. Open woodlands usually have lower phosphorus (P) levels (the main limiting nutrient in Mediterranean forests; Sardans et al. 2004, Morillas et al. 2012) than closed forests, but show much higher loads of P. cinnamomi (Gómez-Aparicio et al. 2012). The selection of these two distinct sites allowed us to explore the variability in the role of PSFs in the dynamics of declining forests at the landscape scale.

To test PSFs in a realistic community context, we focused not only on individual PSFs (i.e., comparing the growth of a plant species on conspecific vs. heterospecific soil) but also calculated net-pairwise PSFs by comparing performance of coexisting tree species on their own and each other's soils. Theoretical models have demonstrated that net-pairwise PSFs can be more important to plant growth than the direction or strength of individual PSFs and are necessary to make accurate predictions of plant-plant interactions and species replacements in plant communities (Bever 2003, Eppinga et al. 2006). However, they have been rarely calculated in empirical studies (Mangan et al. 2010a, Brandt et al. 2013, Kuebbing et al. 2015, Heinze et al. 2016). We hypothesized that: (1) the decline and death of $Q$. suber would cause changes in the direction and strength of individual PSFs of the three species of study ( $Q$. suber, O. europaea, and $Q$. canariensis) compared to healthy trees due to the associated changes in soil nutrients (chemical feedback) and soil biota (biological feedback); (2) the direction and strength of the individual PSFs depend on environmental context. Specifically, we expected stronger chemical and biological PSFs in the open woodland than in the closed forest due to its lower P content and higher pathogen load. This is because PSFs are generally stronger in "extreme" environments (Ehrenfeld et al. 2005, Bezemer et al. 2006); and (3) changes in individual PSFs would translate into changes in net-pairwise interactions at the community level that could affect recruitment dynamics and species coexistence. Specifically, we would expect these changes to promote the replacement of $Q$. suber trees by favoring the relative performance of coexisting species that are not affected by decline.

\section{Materials AND Methods}

\section{Study sites and species}

The study area is located in Los Alcornocales Natural Park, a hotspot of biodiversity in southern Spain (Médail and Quézel 1999). The climate is sub-humid Mediterranean, with most rainfall (95\%) occurring from October to May (Appendix S1: Table S1). Soils are generally sandy, acidic and nutrient poor, derived from a bedrock dominated by Oligo-Miocene sandstones, but are interspersed with soils richer in clay derived from layers of marl sediments. The Alcornocales Natural Park contains the largest and best conserved Quercus suber forests of Europe (Anonymous 2004). In the drier lowlands of the park, $Q$. suber forms mixed open woodlands with the evergreen and shade-intolerant Olea europaea var. sylvestris, whereas in wetter areas $Q$. suber coexists with the deciduous shade-tolerant Quercus canariensis forming closed forests. Trees in open woodlands are generally of smaller size than in closed forests and do not form a continuous canopy layer.

We selected two sites belonging to each of these two main forest types: the open woodland of Ahumada and the closed forest of Comares (Appendix S1: Table S1). Open woodland soils are richer in carbon $(\mathrm{C})$, nitrogen (N) and exchangeable cations $\left(\mathrm{Ca}^{2+}, \mathrm{Mg}^{2+}\right.$, and $\left.\mathrm{K}^{+}\right)$than soils in the closed forest, but are poorer in $\mathrm{P}$ content (Appendix S1: Table S1). The abundance of Phytophthora cinnamomi is two orders of magnitude higher in the woodland than the closed forest site, probably largely due to its higher soil clay content (Appendix S1: Table S1). Clayish soils have high water-holding capacity, low percolation rates and are prone to suffer temporal waterlogging 
(Brady and Weil 2008), conditions that strongly benefit pathogen abundance and disease development (Hendrix and Campbell 1973, Weste and Marks 1987). Accordingly, decline symptoms (measured in terms of relative basal area of defoliated and dead trees) are higher in the open woodland than in the closed forest (Appendix S1: Table S1). Woodland soils also show a higher abundance of arbuscular mycorrhiza (AM) as a consequence of the larger abundance of AM host species (e.g., O. europaea), whereas the abundance of ectomycorrhiza (ECM) tends to be higher in the closed forest site (Appendix S1: Table S1).

\section{Field soil sampling}

Plant species-specific soils for use in feedback tests can be obtained from manipulative greenhouse experiments where neutral/naive soils are conditioned by different plant species (the 'Cultivation-Experiment' approach) or by sampling soil close to established adult plants in the field, i.e., the 'Natural-Experiment' approach (Kulmatiski and Kardol 2008). We chose the 'Natural-Experiment' approach because: (1) soil cultured in the greenhouse may lack critical biotic components found only in soils cultivated in situ (Sykorova et al. 2007, Pendergast et al. 2013); and (2) for tree species, effects might be negligible when greenhouse cultivations are bound to small-sized seedlings or saplings (McCarthy-Neumann and Kobe 2010). In January 2012, we collected soil cores $(7.5 \mathrm{~cm}$ diameter $\times 20 \mathrm{~cm}$ depth $)$ in the two study sites under four different categories of canopy trees (hereafter, soil origins): healthy $Q$. suber trees (without signs of crown defoliation), declining $Q$. suber trees (crown defoliation $>50 \%$ ), dead $Q$. suber trees (with leafless canopy), and healthy adults of the coexisting tree species (O. europaea in the open woodland, $Q$. canariensis in the closed forest). We focused on the upper soil layer $(0-20 \mathrm{~cm})$ because it is where stronger effects of individual trees on soils occur due to high litter inputs and fine root abundance (López et al. 2001, Lovett et al. 2004). At each site, we selected five individuals of average size (i.e., $30-40 \mathrm{~cm}$ diameter at breast height) per tree category that were at a minimum distance of $5 \mathrm{~m}$ from adults of other categories. We collected four soil sub-samples (one per cardinal direction) within $2 \mathrm{~m}$ from the bole of each individual tree in microsites free of understory vegetation, which were combined to generate one composite soil sample (approx. $10 \mathrm{~L}$ ) per tree.

\section{Soil preparation}

The soil samples were directly transported to the laboratory, where they were sieved through a 2-mm mesh to eliminate stones and large roots. Fine roots found in the soil samples were cut into pieces and added to the sieved soil. After every soil sample, all the material in contact with the soil was cleaned with a $10 \%$ bleach solution to prevent cross contamination. In order to separate the net effect of soil biota (biological PSF) from chemical factors (chemical PSF), each soil sample was divided in two halves, one of which was triple sterilized by autoclaving at running vapor for three consecutive days (McCarthy-Neumann and Kobe 2010).

An important side effect of sterilization is that it can result in an increase in nutrient availability (Brinkman et al. 2010). To quantify and correct for this side effect, sterilized and non-sterilized soils were analysed for $\mathrm{NH}_{4}{ }^{+}$ and $\mathrm{NO}_{3}{ }^{-}$(extracted with $1 \mathrm{M} \mathrm{KCl}$ and concentrations determined by spectrophotometry), available P (Bray method, Bray and Kurtz 1945), and exchange cations $\left(\mathrm{Ca}^{2+}, \mathrm{Mg}^{2+}\right.$, and $\mathrm{K}^{+}$, extracted with $1 \mathrm{M}$ ammonium acetate and determined by atomic absorption) previous to the experiment. The results of the analyses showed an increase in $\mathrm{NH}_{4}{ }^{+}$and $\mathrm{PO}_{4}{ }^{3-}$ concentration of sterilized soils, but a decrease in the $\mathrm{NO}_{3}{ }^{-}$concentration (Appendix B). To compensate for this variation, we prepared a fertilizer solution of triammonium phosphate $\left(\left(\mathrm{NH}_{4}\right)_{3} \mathrm{PO}_{4}\right)$ and ammonium sulfate $\left(\left(\mathrm{NH}_{4}\right)_{2} \mathrm{SO}_{4}\right)$ that was added to the non-sterilized samples, and a solution of calcium nitrate $\left(\mathrm{Ca}\left(\mathrm{NO}_{3}\right)_{2}\right)$ that was added to the sterilized soils. Solutions were added at levels required to eliminate differences due to sterilization but without removing the existing chemical differences among soil origins. Thus, soils under dead $Q$. suber trees consistently showed lower $\mathrm{P}$ availability than soils under healthy trees, while defoliated $Q$. suber soils showed intermediate values (Appendix S2: Table S1). Fertilizer solutions were added to the soils at the beginning of the greenhouse experiment (see Greenhouse experiment). After 12 days, we re-analysed the chemical composition of the soil from the experimental pots to confirm the similarity of nutrient levels among sterilized and non-sterilized soils, which was satisfactory (Appendix S3: Table S1). Because the addition of fertilizer solutions implied an increase in the $\mathrm{N}$ and $\mathrm{P}$ levels of the experimental soils, we cannot totally discard the existence of some fertilization effects on the PSFs detected (e.g., Manning et al. 2008). However, nutrient levels in experimental soils remained relatively low (particularly $\mathrm{P}$ ) even after the addition of the fertilizer solutions (Anonymous 1992). Therefore, the resulting PSFs can be considered representative of the P-limited soils of the study area.

\section{Greenhouse experiment}

Seeds of the three study species (Q. suber, O. europaea and Q. canariensis) were collected during fall 2011 from several trees in the study zone and were mixed to obtain one unique pool per species. Seeds were stored in humid substrate at $4^{\circ} \mathrm{C}$ until sowing. Before sowing, healthy acorns of the two Quercus species were selected by flotation (Gribko and Jones 1995). To reduce differences in the response to soil properties due to differences in acorn size, we selected only healthy acorns with a weight within the first and third quartile $(25-75 \%)$ of the whole acorn population (i.e., $4.68-7.21 \mathrm{~g}$ for $Q$. suber and $4.71-6.16 \mathrm{~g}$ for $Q$. canariensis). Selected acorns were 
surface-sterilized with a $10 \%$ bleach solution previous to planting. Seeds of $O$. europaea show double dormancy and their germination rate under natural conditions is generally low $(<20 \%$, Rey et al. 2004; J. DomínguezBegines, unpublished data). Therefore, we decided to use seedlings germinated in vitro. We first extracted the seed following Sotomayor-León and Caballero (1990), then the embryo was separated from the endosperm and sown in tubes with RUGINI $+10 \mathrm{~g} / \mathrm{L}$ sucrose medium (García 1999). Tubes were kept in a growth chamber $\left(23 \pm 1{ }^{\circ} \mathrm{C}, 16 \mathrm{~h} /\right.$ day photoperiod) until the seedlings were transplanted. As for acorns, only seedlings of intermediate size $(3.92 \pm 0.10 \mathrm{~cm})$ were used.

The experiment was set up in January 2012. Soil samples were homogenized within soil origins for each site (open woodland vs. closed forest) and sterilization treatment (sterilized vs. non-sterilized), resulting in 8 soil types per site (i.e., 2 sterilization treatments $\times 4$ soil origins). Ten seed/seedlings of each of the two dominant tree species at each site (i.e., $Q$. suber and $O$. europaea in the open woodland, Q. suber and Q. canariensis in the closed forest) were individually planted in $1-\mathrm{L}$ pots filled with soil from each of the 8 soil types from the same site, resulting in a total of 320 pots (i.e., 2 sites $\times 2$ sterilization treatments $\times 4$ soil origins $\times 2$ seedling species $x$ 10 replicates). Light levels in the greenhouse resembled the light conditions of the forest understory (i.e., PAR $300 \mu \mathrm{mol} \cdot \mathrm{m}^{-2} \mathrm{~s}^{-1}$ ). Pots were watered to saturation 2-3 times weekly, such that water was not a limiting factor for seedling performance. Pots were randomly distributed within the greenhouse and repositioned monthly. Acorn emergence was censused weekly for 2 months (January-February). Acorns that had not emerged by the end of February $(15 \%)$ were replaced with a new seedling coming from a reserve sown in supplementary pots with the corresponding soils. Seedling survival was recorded periodically for five months, but no seedlings died throughout the experiment.

\section{Seedling measurements}

In the beginning of June (i.e., 5 months after planting), all surviving seedlings were harvested. Each seedling was divided into stem, leaves and roots. Fresh samples were used to measure stem height, stem basal diameter, leaf area using the program Image Pro-plus 6.0 (Media Cybernetic Inc., Rockville, Maryland, USA), fine root traits using the WinRhizo program (Regent Instruments Inc., Quebec, Canada), and mycorrhizal root colonization. We focused on two root traits shown to be part of a root trait syndrome that regulates species responses to shifts in environmental conditions: specific root length (SRL, root length per unit of dry mass) and tissue mass density (TMDr, root dry mass per volume). The type of mycorrhiza measured in each seedling species was chosen based on their most common mycorrhizal status: ectomycorrhizal (ECM) for Quercus species (Smith and Read 2008) and arbuscular mycorrhizal (AM) for O. europaea (Roldán-Fajardo and Barea 1985). The percentage of ECM colonization was estimated following the gridline intersection method (Brundett et al. 1996). Roots were placed in a Petri dish with a grid of $1.2 \mathrm{~cm}$ and observed under a stereomicroscope. Quantification was carried out on the basis of morphological features of the fine roots (i.e., visible mantle around the root tips). For quantification of AM infection, roots were cleared for $15 \mathrm{~min}$ in $10 \% \mathrm{KOH}$ at $85^{\circ} \mathrm{C}$ and rinsed in water. Roots were then stained with the ink-vinegar method (Vierheilig et al. 1998). Stained roots were mounted in $60 \%$ lactic acid and inspected at $200 \times$ magnification in samples of $301-\mathrm{cm}$ sections. The percentage of AM colonization was estimated following the method described by Trouvelot et al. (1986). Finally, all plant material was dried at $70^{\circ} \mathrm{C}$ for a minimum of $48 \mathrm{~h}$ to estimate shoot biomass, root biomass, and root mass fraction (RMF, root dry mass per unit of total plant dry mass). Total biomass (i.e., shoot + root biomass) was strongly correlated $(r>0.95)$ with shoot biomass for all species and site combinations, and therefore it was not included in the statistical analyses. Leaf area and biomass data were used to calculate the specific leaf area (SLA, leaf area per unit of dry leaf mass).

\section{Statistical analyses}

Emergence of oak seedlings was analyzed using two complementary analyses: survival analysis of emergence times using Cox proportional hazards (Cox and Oakes 1984) and analysis of final emergence using Generalized Linear Models (GLMs) with binomial distribution. In both cases, soil origin (i.e., healthy $Q$. suber trees, declining $Q$. suber trees, dead $Q$. suber trees, and the coexisting tree species at each site-O. europaea or $Q$. canariensis) and sterilization were used as fixed factors, whereas acorn size was used as a covariable. GLMs were also used to test the effects of soil origin, sterilization and their interaction on aboveground (shoot biomass, stem height, basal diameter, SLA) and belowground (root biomass, RMF, SRL, TMDr, \% mycorrhizal colonization) seedling traits, with acorn size/seedling height as a covariable. Analyses were conducted for each combination of seedling species and forest type separately. All traits were analyzed using a normal distribution of errors, but for $\%$ mycorrhizal colonization that followed a binomial distribution. When a factor or interaction was significant, differences among treatments or treatment combinations were tested using post-hoc Tukey tests. To minimize the risk of Type I errors resulting from the analysis of multiple seedling traits, we controlled the False Discovery Rata (FDR) at 5\% using the procedure "step-up" (Garcia 2003, García 2004).

We based our interpretation of individual PSFs (direction and strength) on the among-soil differences in seedling shoot and root biomass detected by the GLMs, since this statistical approach usually has higher flexibility and statistical power than the analysis of feedback 
values (Brinkman et al. 2010). However, we also calculated individual PSFs between conspecific (con) and heterospecific (het) soils as $\ln (\mathrm{con} / \mathrm{het}$ ) in order to facilitate the comparison of our results with previous PSFs studies. This PSF calculation centers feedback values around 0 (i.e., maximum PSFs are -1 and 1), which allows for easier comparison of negative and positive values (Brinkman et al. 2010). We calculated six individual PSFs per seedling species and site, by comparing shoot and root biomass in non-sterilized soils from $Q$. suber of different health status (healthy, defoliated and dead) vs. non-sterilized soils from the coexisting species (O. europaea or $Q$. canariensis). Because we did not have natural pot pairings, we followed Kuebbing et al. (2015) and calculated PSFs using all possible combinations of pot pairs. We had 10 seedlings per soil origin, which resulted in 100 values $(10$ con $\times 10$ het) for each individual PSF. An individual PSF was considered to be significantly positive or negative when the confidence interval for the mean of the distribution did not overlap zero.

We tested for community PSFs by quantifying net-pairwise interactions at each of the two forest types using the interaction coefficient $\left(I_{\mathrm{s}}\right)$ following Bever et al. (1997). This index is calculated as the difference among intra- vs. inter-specific effects: $I_{\mathrm{S}}=\left(\alpha_{\mathrm{A}}+\beta_{\mathrm{B}}\right)-\left(\alpha_{\mathrm{B}}+\beta_{\mathrm{A}}\right)$, where $\alpha_{\mathrm{A}}$ and $\beta_{\mathrm{B}}$ measure conspecific effects and $\alpha_{\mathrm{B}}$ and $\beta_{\mathrm{A}}$ measure heterospecific effects. Positive $I_{\mathrm{S}}$ values indicate net positive feedbacks considered to promote competitive exclusion, whereas negative $I_{\mathrm{s}}$ values indicate net negative feedbacks considered to promote coexistence (Bever et al. 1997). We calculated six indices per site, resulting from comparing shoot and root biomass in non-sterilized soils from $Q$. suber of different health status (healthy, defoliated and dead) vs. non-sterilized soils from the coexisting species (O. europaea or $Q$. canariensis). Indices were calculated using mean values of shoot and root biomass in each soil origin. Confidence intervals were calculated by sampling with replacement for 9,999 iterations to determine whether the mean coefficient was significantly different from zero. All analyses were conducted using $\mathrm{R}$ 3.0.2 (R Core Team 2013).

\section{Results}

Time to emergence was not affected by soil origin, sterilization or acorn size (Appendix S4: Table S1), and neither was the final percentage of emerged seedlings ( $P>0.05$ in all cases). Seedlings of both Quercus suber and Quercus canariensis emerged continuously during the first and second month of the experiment reaching emergence percentages of $75 \%$ in soils from the open woodland and $90 \%$ in soils from the closed forest.

The effects of soil origin and sterilization on aboveand below-ground seedling traits varied among forest types and seedling species. In the open woodland, soil origin did not affect aboveground traits of $Q$. suber seedlings and only affected two belowground traits, the SRL and the $\%$ mycorrhizal colonization (Table 1, Figs. 1a, 2a, 3a). The SRL of $Q$. suber seedlings was lower in soils from dead conspecific trees $(29.87 \pm 1.37 \mathrm{~cm} / \mathrm{g})$ than in any of the other soils $(32-37 \mathrm{~cm} / \mathrm{g})$. The percentage of mycorrhizal colonization was lower in soils from heterospecific than from healthy conspecific trees, but did not show any clear trend with $Q$. suber decline (Fig. 3a). Differences among soils in mycorrhizal colonization of $Q$. suber disappeared with sterilization (significant Soil origin $\times$ Sterilization interaction, Table 1). Soil sterilization did not affect aboveground traits of $Q$.

TABLE 1. General linear models ( $F$ values) and generalized linear models ( $L-R \chi^{2}$ values for mycorrhizal colonization) analyzing differences among soil origins and sterilization treatments in above- and below-ground traits of Quercus suber and Olea europaea seedlings from the open woodland.

\begin{tabular}{|c|c|c|c|c|c|c|c|c|c|c|c|}
\hline \multirow[b]{2}{*}{ Species } & \multirow[b]{2}{*}{ Factor } & \multirow[b]{2}{*}{$\mathrm{df}$} & \multicolumn{4}{|c|}{ Above-ground traits } & \multicolumn{5}{|c|}{ Below-ground traits } \\
\hline & & & $\begin{array}{c}\text { Shoot } \\
\text { biomass }\end{array}$ & $\begin{array}{l}\text { Stem } \\
\text { height }\end{array}$ & $\begin{array}{c}\text { Basal } \\
\text { diameter }\end{array}$ & SLA & $\begin{array}{c}\text { Root } \\
\text { biomass }\end{array}$ & RMF & SRL & TMDr & $\begin{array}{l}\text { Mycorrhizal } \\
\text { colonization }\end{array}$ \\
\hline \multirow[t]{6}{*}{ Q. suber } & Soil origin (SO) & 3 & 0.85 & 0.92 & 2.60 & $2.81 *$ & 1.75 & 2.08 & $3.32 *$ & 1.02 & $19.15 * * *$ \\
\hline & Sterilization (S) & 1 & 3.59 & 3.45 & 2.04 & 0.58 & $16.36^{* * * *}$ & 0.04 & $3.77 *$ & $9.09 * *$ & $68.00 * * * *$ \\
\hline & $\mathrm{SO} \times \mathrm{S}$ & 3 & 0.34 & 0.56 & 0.58 & 0.70 & 0.50 & 0.47 & 2.21 & 1.43 & $17.39 * * *$ \\
\hline & Acorn size & 1 & 1.91 & 0.47 & $13.91 * * *$ & 0.80 & 1.78 & 0.10 & 0.36 & 0.18 & $10.91 * *$ \\
\hline & Model & 8,71 & $2.66^{*}$ & $2.21 *$ & $3.94 * * *$ & 1.77 & $4.59 * * *$ & 1.08 & $2.62 \%$ & $2.06^{*}$ & $173.51 * * * *$ \\
\hline & $R^{2}$ & & 0.23 & 0.20 & 0.31 & 0.11 & 0.34 & 0.07 & 0.22 & 0.18 & 0.10 \\
\hline \multirow[t]{6}{*}{ O. europaea } & Soil origin (SO) & 3 & $3.14 *$ & $5.58 * *$ & 2.46 & 1.49 & $4.37 * *$ & 1.12 & $2.41 *$ & 2.19 & $36.03^{* * * *}$ \\
\hline & Sterilization (S) & 1 & $96.21 * * * *$ & $163.66 * * * *$ & $19.26 * * * *$ & $19.38^{* * * *}$ & $9.37 * *$ & $114.49 * * * *$ & 1.39 & $3.50 *$ & $1342.83 * * * *$ \\
\hline & $\mathrm{SO} \times \mathrm{S}$ & 3 & $3.09 *$ & $4.12 * *$ & $3.47^{*}$ & $4.58 * *$ & 0.56 & $4.46^{* *}$ & 1.29 & 0.46 & $34.27 * * * *$ \\
\hline & $\begin{array}{c}\text { Initial seedling } \\
\text { height }\end{array}$ & 1 & 0.00 & 0.05 & 1.39 & 0.31 & 0.56 & 0.85 & 0.11 & 1.18 & 0.09 \\
\hline & Model & 8,71 & $14.40 * * * *$ & $24.11 * * * *$ & $4.87 * * * *$ & $5.25 * * * *$ & $7.53 * *$ & $11.53 * * * *$ & 1.60 & 1.68 & $1429.94 * * * *$ \\
\hline & $R^{2}$ & & 0.62 & 0.73 & 0.39 & 0.41 & 0.46 & 0.65 & 0.15 & 0.16 & 0.43 \\
\hline
\end{tabular}

Notes: SLA, specific leaf area; RMF, root mass fraction; SRL, specific root length; TMDr, root tissue mass density.

Acorn size (for $Q$. suber) and initial seedling height (for $O$. europaea) were included as covariables in the models.

Significance levels: $* * * * P<0.0001, * * * P<0.001, * * P<0.01, * P<0.05$. After FDR correction using the "step-up" procedure, differences were considered significant at $P<0.008$ for $Q$. suber and $P<0.032$ for $O$. europaea (highlighted in bold). 

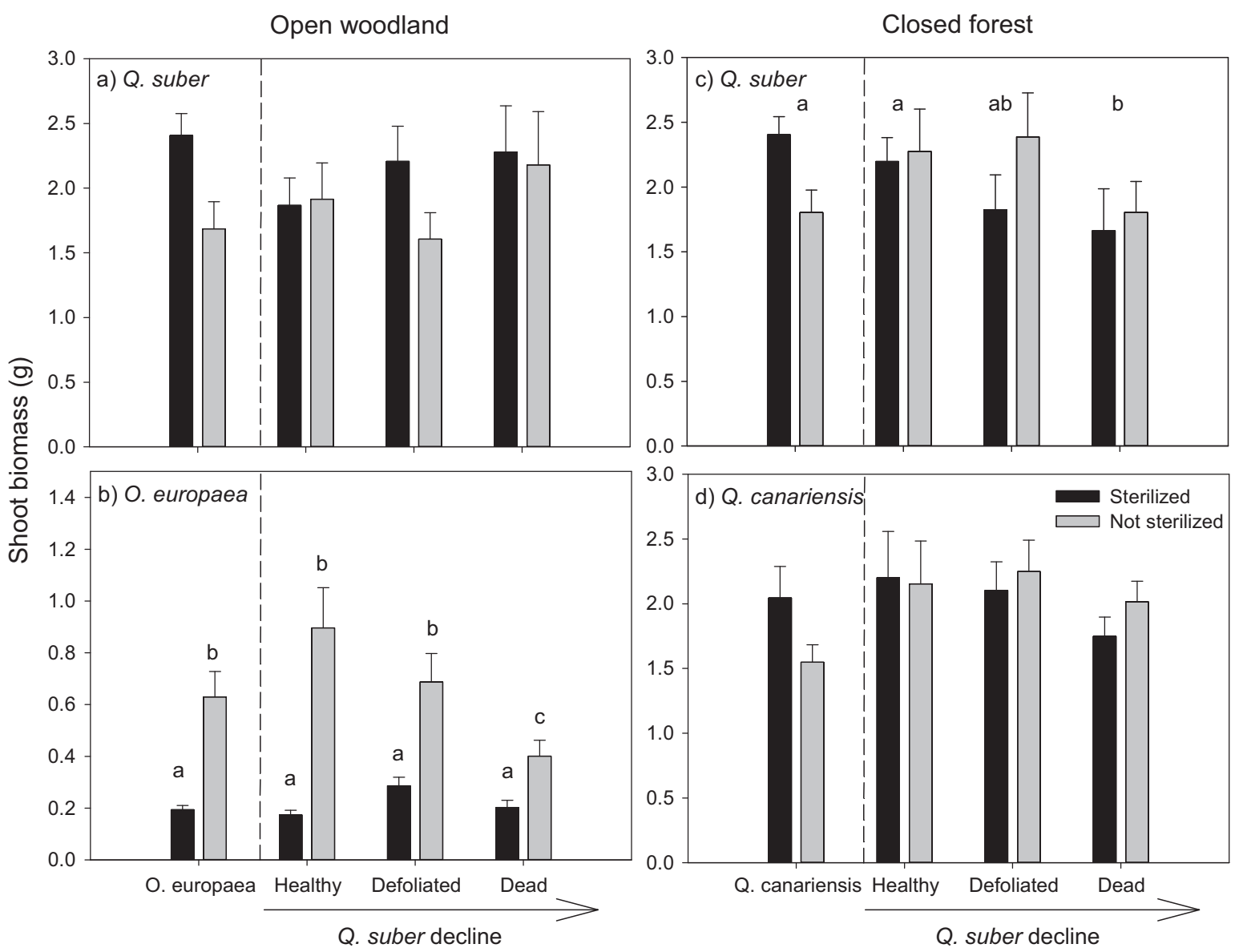

\section{Soil origin}

FIG. 1. Effects of soil origin (SO) and soil sterilization (S) on shoot dry biomass of (a) Quercus suber and (b) Olea europaea seedlings in soils from the open woodland, and of (c) Q. suber and (d) Quercus canariensis seedlings in soils from the closed forest. Data represent mean $\pm \mathrm{SE}(n=10)$. When a significant SO effect or SO $\times \mathrm{S}$ interaction was found (Table 1) different letters show significant differences after Tukey tests.

suber seedlings in woodland soils, but had large effects on belowground traits mostly independent of soil origin (Table 1). Q. suber seedlings in sterilized soils showed higher root biomass (Fig. 2a) and lower TMDr $\left(462.01 \pm 19.75\right.$ vs. $\left.544.21 \pm 19.18 \mathrm{~g} / \mathrm{cm}^{3}\right)$ than seedlings in non-sterilized soils. Contrary to $Q$. suber, soil origin had strong effects on Olea europaea, which showed higher seedling shoot and root biomass, stem height, basal diameter, RMF, mycorrhizal colonization, and lower SLA in conspecific and healthy $Q$. suber soils than in dead $Q$. suber soils; soils from defoliated $Q$. suber frequently showed intermediate values (Table 1, Figs. 1b, 2b, 3b). Soil origin interacted with sterilization for most $O$. europaea traits (Table 1), differences among soils disappearing in sterilized soils (Figs. 1b, 3b) and suggesting that soil microbes were the drivers of the soil origin effects on seedling performance. Soil sterilization had strong effects on above- and below-ground traits of O. europaea, which were generally much lower (except for RMF, which was higher) in sterilized soils.
In closed forests, soil origin affected both above- and below-ground traits of $Q$. suber seedlings, but had no effect on $Q$. canariensis except for mycorrhizal colonization (Table 2). Quercus suber seedlings in soils from healthy conspecific and heterospecific trees showed higher shoot biomass (Fig. 1c), basal diameter, and root biomass (Fig. 2c) than seedlings from dead soils; seedlings in defoliated $Q$. suber soils showed intermediate values. These soil effects were independent of soil sterilization (Table 2), suggesting a chemical nature of the soil effects on seedling performance. The $\%$ mycorrhizal colonization of both $Q$. suber and $Q$. canariensis seedlings was generally highest in soils from $Q$. canariensis and lowest in soils from healthy $Q$. suber, with seedlings in soils from defoliated and dead $Q$. suber showing intermediate values (Fig. 3c, d). Differences among soil origins in mycorrhizal colonization disappeared with sterilization (Table 2). Soil sterilization did not have direct effects on any growth variable of the two seedling species, except for the stem height of $Q$. suber seedlings 


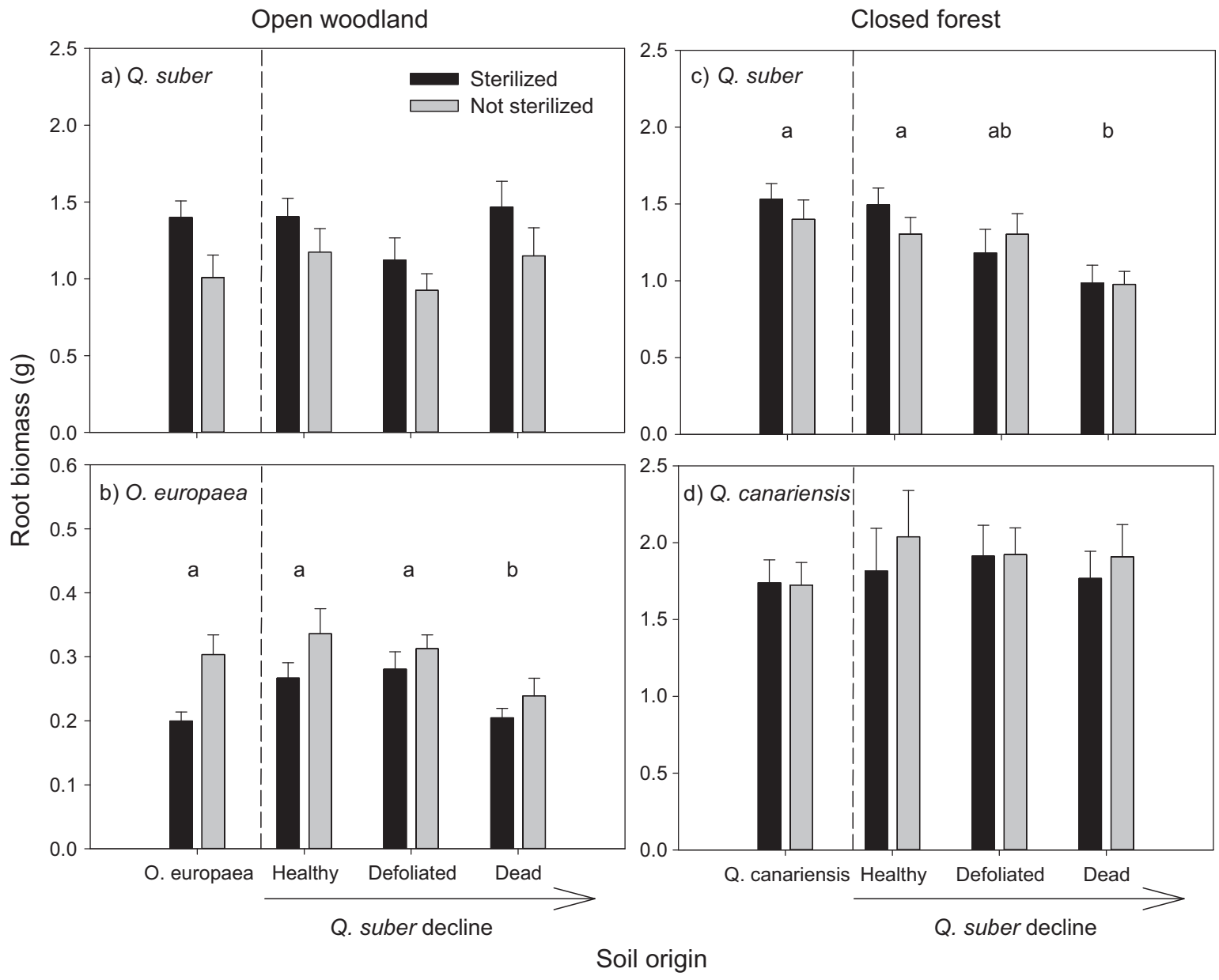

FIG. 2. Effects of soil origin (SO) and soil sterilization (S) on root dry biomass of (a) Quercus suber and (b) Olea europaea seedlings in soils from the open woodland, and of (c) Q. suber and (d) Quercus canariensis seedlings in soils from the closed forest. Data represent mean $\pm \mathrm{SE}(n=10)$. When a significant SO effect was found (Table 1) different letters show significant differences after Tukey tests.

(Table 2) which was higher in non-sterilized than sterilized soils $(29.83 \pm 1.48$ vs. $25.19 \pm 0.99 \mathrm{~cm})$.

Net-pairwise feedback values $\left(I_{\mathrm{s}}\right)$ were neutral when considering soils from healthy $Q$. suber trees (Fig. 4), which could be attributed to the mostly neutral individual PSFs (Fig. 5). However, the defoliation and death of $Q$. suber caused a change in the direction and strength of the $I_{\mathrm{s}}$ index, becoming positive in the open woodland and negative in the closed forest (Fig. 4). This pattern was consistent above- and below-ground (Fig. 4). The change towards positive $I_{\mathrm{s}}$ values at the woodland site under a decline scenario (i.e., when considering soils from defoliated and dead $Q$. suber trees) could be mainly attributed to more beneficial conspecific effects (i.e., more positive individual PSFs) for O. europaea (Fig. 5), whereas the change towards negative $I_{\mathrm{s}}$ values at the closed forest site could be attributed to stronger negative conspecific than heterospecific effects (i.e., more negative individual PSFs) for both species but particularly for Q. suber (Fig. 5).

\section{DisCUSSION}

H1: The decline and death of Quercus suber causes changes in the direction and strength of individual PSFs compared to healthy reference trees

This study provides novel evidence showing that the decline of a dominant tree species $(Q$. suber) induced by an exotic pathogen (Phytophthora cinnamomi) translated into substantial alterations of the direction and strength of individual PSFs in Mediterranean forests due to the associated changes in soil abiotic and biotic characteristics. Moreover, we found that the direction of these changes varied among coexisting species in our study sites. In the open woodland, the decline of $Q$. suber did not affect conspecific seedlings but translated into positive PSFs in Olea europaea seedlings, which experienced a $39 \%$ and $20 \%$ increase in shoot and root biomass, 

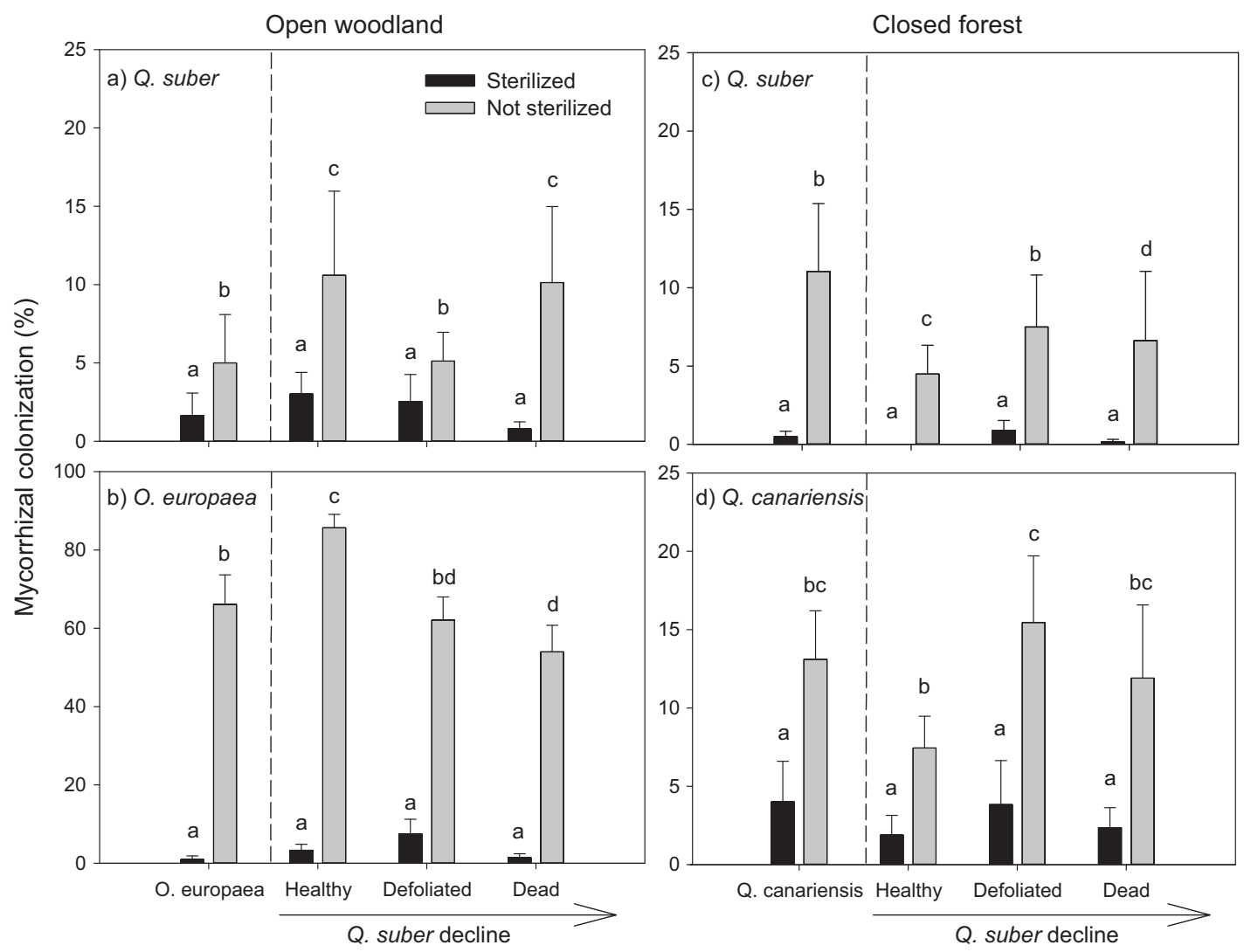

Soil origin

FIG. 3. Effects of soil origin (SO) and soil sterilization (S) on \% mycorrhizal colonization of (a) Quercus suber and (b) Olea europaea roots in soils from the open woodland, and of (c) Q. suber and (d) Quercus canariensis seedling roots in soils from the closed forest. Data represent mean $\pm \mathrm{SE}(n=10)$. When a significant $\mathrm{SO} \times \mathrm{S}$ interaction was found (Table 1) different letters show significant differences after Tukey tests.

TABLE 2. General linear models ( $F$ values) and generalized linear models ( $L-R \chi^{2}$ values for mycorrhizal colonization) analyzing differences among soil origins and sterilization treatments in above- and below-ground traits of Quercus suber and Quercus canariensis seedlings from the closed forest.

\begin{tabular}{|c|c|c|c|c|c|c|c|c|c|c|c|}
\hline \multirow[b]{2}{*}{ Species } & \multirow[b]{2}{*}{ Factor } & \multirow[b]{2}{*}{ df } & \multicolumn{4}{|c|}{ Above-ground traits } & \multicolumn{5}{|c|}{ Below-ground traits } \\
\hline & & & $\begin{array}{c}\text { Shoot } \\
\text { biomass }\end{array}$ & $\begin{array}{l}\text { Stem } \\
\text { height }\end{array}$ & $\begin{array}{c}\text { Basal } \\
\text { diameter }\end{array}$ & SLA & $\begin{array}{c}\text { Root } \\
\text { biomass }\end{array}$ & $\mathrm{RMF}$ & SRL & TMDr & $\begin{array}{l}\text { Mycorrhizal } \\
\text { colonization }\end{array}$ \\
\hline \multirow[t]{6}{*}{ Q. suber } & Soil origin $(\mathrm{SO})$ & 3 & $3.42 *$ & 1.28 & $3.51 *$ & 0.77 & $7.58 * * *$ & 0.45 & $3.16^{*}$ & 1.24 & $14.41 * *$ \\
\hline & Sterilization (S) & 1 & 0.25 & $7.03 * *$ & 0.64 & 0.64 & 0.28 & 0.82 & 1.49 & 1.67 & $137.19 * * * *$ \\
\hline & $\mathrm{SO} \times \mathrm{S}$ & 3 & 2.35 & 0.52 & 0.51 & 034 & 0.84 & 1.72 & 0.24 & 0.12 & $15.43^{* *}$ \\
\hline & Acorn size & 1 & $6.80 *$ & $6.34 *$ & 1.21 & 0.81 & 2.59 & $5.59 *$ & 1.05 & 0.40 & $50.97 * * * *$ \\
\hline & Model & 8,71 & $2.87 *$ & $3.06^{*}$ & $2.31 *$ & 0.28 & $3.19 * *$ & 1.77 & 1.48 & 0.71 & $278.01 * * * *$ \\
\hline & $R^{2}$ & & 0.16 & 0.17 & 0.13 & 0.02 & 0.37 & 0.16 & 0.14 & 0.07 & 0.14 \\
\hline \multirow[t]{6}{*}{ Q. canariensis } & Soil origin (SO) & 3 & 1.70 & 0.88 & 0.87 & 0.44 & 0.84 & 0.60 & 1.88 & 0.23 & $37.78 * * * *$ \\
\hline & Sterilization (S) & 1 & 0.00 & 0.45 & 1.69 & 0.20 & 0.67 & 0.78 & 0.28 & 0.49 & $310.70 * * * *$ \\
\hline & $\mathrm{SO} \times \mathrm{S}$ & 3 & 0.92 & 0.75 & 0.56 & 0.40 & 0.74 & 0.21 & 0.98 & $5.11 * *$ & $28.82 * * * *$ \\
\hline & Acorn size & 1 & 1.74 & 2.22 & 0.43 & 0.82 & $6.68^{*}$ & 0.35 & 0.91 & 0.01 & $58.84 * * * *$ \\
\hline & Model & 8,71 & 1.45 & 0.87 & 0.91 & 0.94 & 1.09 & 1.01 & 1.18 & $2.07 *$ & $509.59 * * * *$ \\
\hline & $R^{2}$ & & 0.09 & 0.06 & 0.06 & 0.06 & 0.10 & 0.10 & 0.11 & 0.19 & 0.10 \\
\hline
\end{tabular}

Notes: SLA, specific leaf area; RMF, root mass fraction; SRL, specific root lenght; TMDr, root tissue mass density.

Acorn size was included as covariable in the models

Significance levels: ${ }^{* * * *} P<0.0001,{ }^{* * *} P<0.001, * * P<0.01, * P<0.05$. After FDR correction using the "step-up" procedure, differences were considered significant at $P<0.021$ for $Q$. suber and $P<0.0001$ for $Q$. canariensis (highlighted in bold). 


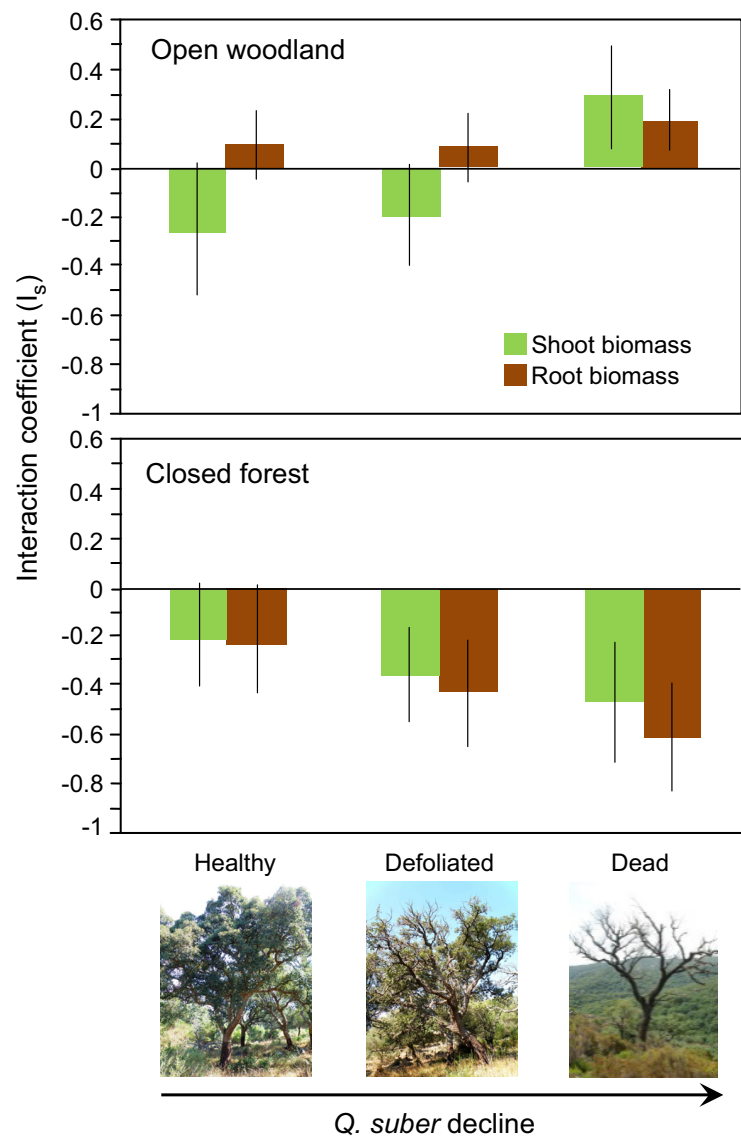

FIG. 4. Mean interaction coefficients $\left(I_{\mathrm{s}}\right)$ for net pairwise plant-soil feedbacks at the two study sites. Interaction coefficients were calculated comparing above- and below-ground seedling biomass of each species pair (Quercus suber-O. europaea in open woodland, Q. suber-Quercus canariensis in closed forest) in non-sterilized soils from $Q$. suber of different health status (healthy, defoliated and dead) vs. non-sterilized soils from the coexisting species (O. europaea or $Q$. canariensis). Indices were considered to be significantly positive or negative when confidence intervals did not overlap zero. Positive $I_{\mathrm{s}}$ values indicate net positive feedbacks considered to promote competitive exclusion, whereas negative $I_{\mathrm{s}}$ values indicate net negative feedbacks considered to promote species coexistence.

respectively, when growing in conspecific soils compared to soils from dead Q. suber. Meanwhile, in the closed forest the decline of $Q$. suber translated into strong negative conspecific PSFs, with Q. suber seedlings showing a $20 \%$ and $36 \%$ decrease in shoot and root biomass, respectively, in soils from dead conspecifics compared to heterospecifics, whereas Quercus canariensis seedlings were unaffected. The fact that $Q$. canariensis, the most shadetolerant of the three study species, was the only species that did not suffer from any PSF concurs with previous studies showing weak PSFs for shade-tolerant species, due to their typical conservative strategies characterized by moderate resource consumption rates and a high investment in defense (O'Hanlon-Manners and Kotanen 2004, Reinhart et al. 2005, McCarthy-Neumann and
Kobe 2008). Overall, although the type of individual PSFs generated by the decline of $Q$. suber was strongly species-specific, in both forest types PSFs benefited other tree species more than $Q$. suber itself (i.e., heterospecific positive feedback in the open woodland and conspecific negative feedback in the closed forest). These effects could imply a competitive disadvantage for Q. suber with negative consequences for maintaining of its dominance, as indicated by previous studies that have shown correlations between the strength of negative PSFs and tree-species relative abundance in forest communities (Mangan et al. 2010a, Johnson et al. 2012).

$\mathrm{H} 2$ : The direction, strength and nature of individual PSFs depends on environmental context

In order to understand the potential role of PSFs for plant community dynamics it is important to assess their consistency at large spatial scales (Smith and Reynolds 2015). To date, the extent to which the incidence and outcome of PSFs vary with soil conditions is still poorly known, with some studies showing feedback effects to vary with soil type or fertility (Bezemer et al. 2006, Manning et al. 2008, Larios and Suding 2015) and others showing feedback effects independent of soil conditions (Casper et al. 2008, Harrison and Bardgett 2010, Perkins and Nowak 2013). In this study, the consideration of two forest types (i.e., open woodland and closed forest) with contrasting physico-chemical (e.g., texture, nutrient content) and biological (e.g., pathogen and mycorrhiza abundance) soil characteristics allowed us to explore the role of PSFs in the dynamics of declining Quercus suber forests at the landscape scale. In support of our second hypothesis, we found that the direction, strength, and nature of PSFs strongly differed between the two forest types.

We predicted stronger chemical and biological PSFs to occur in the clayish soils of the open woodland, characterized by lower $\mathrm{P}$ content but much larger abundance of $P$. cinnamomi than the sandier soils of the closed forest (Gómez-Aparicio et al. 2012). However, our results were not in line with these predictions. Stronger chemical PSFs in the woodland were expected because of stronger $\mathrm{P}$ limitation (i.e., $51 \%$ lower $\mathrm{PO}_{4}{ }^{3-}$ concentration than in the closed forest, Appendix S2: Table S1) and the fact that limiting nutrients can be important drivers of PSFs, particularly under stressful conditions (Bezemer et al. 2006, Smith and Reynolds 2015). However, chemical PSFs were only detected in the closed forest and only for $Q$. suber, with the strength of PSFs increasing with $Q$. suber decline. The occurrence of strong chemical PSFs in the closed forest and not in the open woodland could be explained by the fact that although at both sites the defoliation and death of $Q$. suber resulted in a decrease in soil $\mathrm{P}$ availability, the magnitude of this change was higher in the relatively P-rich closed forest than in the Ppoor open woodland (Appendix S2: Table S1). This result is in line with previous studies showing that tree 


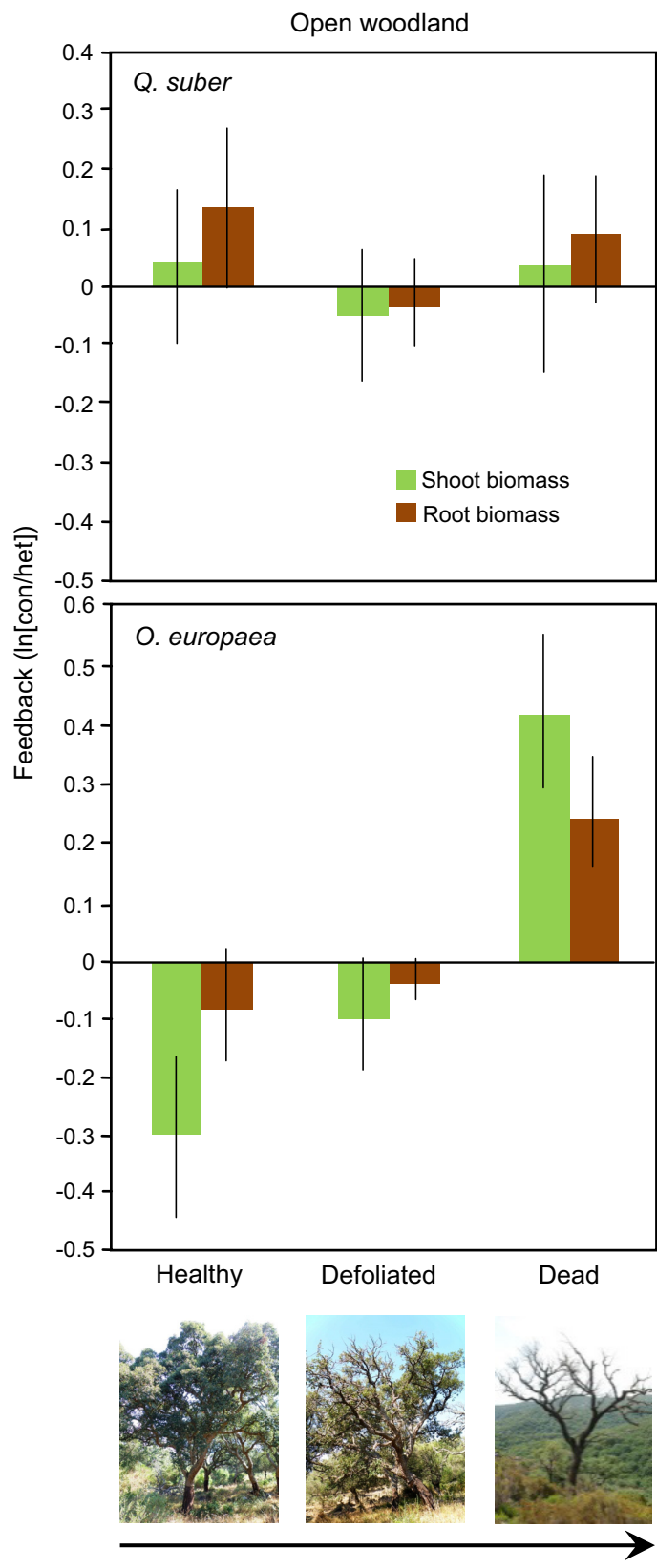

Q. suber decline
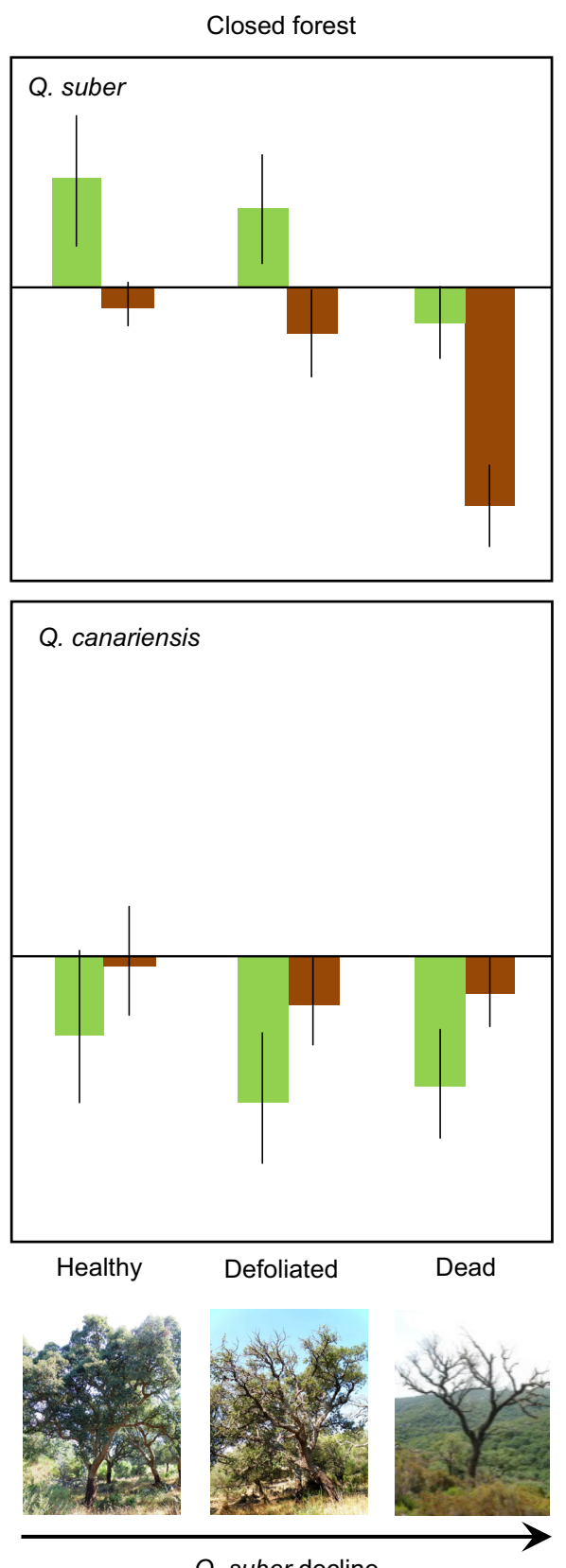

Q. suber decline

FIG. 5. Individual plant-soil feedbacks (PSFs) for the different seedling species at the two study sites. Six individual PSFs were calculated per seedling species and site, by comparing shoot and root biomass in non-sterilized soils from Quercus suber of different health status (healthy, defoliated and dead) vs. non-sterilized soils from the coexisting species (O. europaea or Quercus canariensis). Indices were considered to be significantly positive or negative when confidence intervals did not overlap zero.

impacts on soil chemistry are larger in fertile sites (Finzi et al. 1998, Gómez-Aparicio and Canham 2008). Overall, our results support the idea that limiting nutrients are important drivers of chemical PSFs, but suggest that these PSFs are more likely to occur at high nutrient availability due to a higher likelihood of detecting the chemical footprint of plants.
The lack of biological PSFs driven by pathogens at the woodland site was also surprising, particularly for $Q$. suber, given its susceptibility to $P$. cinnamomi and the marked spatial variation in the abundance of this pathogen in Mediterranean forests. Notably, in a field study conducted at the same sites, Gómez-Aparicio et al. (2012) showed P. cinnamomi abundance to be much 
higher under defoliated $Q$. suber than under healthy and dead $Q$. suber trees, with $O$. europaea soils showing the lowest abundance. The fact that sterilization had a strong positive effect on root biomass of $Q$. suber independent of soil origin indicates that soil pathogens had a general negative effect in the woodland. Similar results have been found in other studies showing how soil antagonists can have a general negative effect on plant growth independently of the soil type (Reinhart et al. 2005, McCarthy-Neumann and Kobe 2010). We propose that these results are likely to be found when pathogen abundance is high, so that despite variation in abundance (e.g., 63-1,476 colony forming units (cfu)/g dry soil in the woodland, Gómez-Aparicio et al. 2012) pathogens always maintain threshold population sizes for disease expression (i.e., $61 \mathrm{cfu} / \mathrm{g}$ for $P$. cinnamomi in Q. suber, Serrano et al. 2015). Another relevant implication of soil sterilization effects on below- but not aboveground traits independent of soil origin is that soil microorganisms can have important effects on plant roots that are not necessarily reflected aboveground. Here, $Q$. suber seedlings growing in sterilized soil did not only show higher root biomass but also much lower TMDr indicative of a lower investment in root structural features. This could be interpreted as reduce need to invest in defense in the absence of $P$. cinnamomi, since lighter tissues are usually associated with an exploitative resource-use strategy that comes at the cost of lower protection against antagonists (Liu et al. 2010). Since most PSF studies focus on the aboveground part of plants (Kulmatiski et al. 2008), it is possible that the role of microorganisms in these processes has so far been underestimated.

Interestingly, although we did not find negative biological PSFs driven by pathogens in the open woodland as hypothesized, we found strong positive biological PSF for $O$. europaea, most likely driven by AM fungi. The growth of $O$. europaea strongly depended on soil biota: soil sterilization reduced aboveground biomass and leaf area up to $80 \%$, and shifted root traits towards maximizing resource acquisition (i.e., larger RMF and lower TMDr, Comas and Eissentat 2009, Pérez-Ramos et al. 2012). The likely role of AM fungi as drivers of this positive soil biota effect and the associated PSF under a decline scenario (i.e., when considering soils from declining instead of healthy $Q$. suber trees) is strongly supported by the positive relationship found between $O$. europaea biomass and AM colonization (Appendix S5: Fig. S1) and the marked response of AM colonization to Q. suber decline. The percentage of AM colonization of O. europaea seedlings decreased from $88 \%$ in soils from healthy $Q$. suber to $56 \%$ in soils from dead $Q$. suber. As a result, under a decline scenario mycorrhizal colonization of $O$. europaea seedlings was higher in conspecific soils $(+68 \%)$ than in heterospecific soils, translating to higher above- and below-ground biomass production. This strong negative soil-mediated effect of the decline of $Q$. suber (a typical ECM species) on AM colonization of $O$. europaea might sound counterintuitive. However, there is evidence that Quercus spp. can also form AM associations (e.g., Dickie et al. 2001). Notably, in a previous field experiment we found similar probability of AM colonization of oak seedlings in tree neighborhoods dominated by $O$. europaea and by healthy $Q$. suber (Ibáñez et al. 2015). Taken together, our results provide novel evidence for an important role of AM fungi as drivers of positive PSFs in Mediterranean forests, which supports recent findings in tropical forests (Mangan et al. 2010b) but contrasts with the negative AM-mediated PSFs frequently found in grasslands (Bever 2002, Castelli and Casper 2003, Bever et al. 2010).

H3: Changes in individual PSFs translate into changes in net-pairwise interactions at the community level

In support of our third hypothesis, we found that changes in individual PSFs with decline of $Q$. suber translated into changes in net-pairwise feedbacks at the community level. Whereas neutral net-pairwise feedbacks dominated in soils from healthy trees, significant net feedbacks were found when soils from defoliated and dead $Q$. suber trees were considered. Interestingly, the direction of the net feedback varied among forest types, being positive in the open woodland and negative in the closed forest. A positive net-pairwise index is found when one or both species alters the soil in a way that favors their own growth more than the growth of heterospecifics, which can destabilize communities and result in dominance by one species (Bever et al. 1997). The positive value of the $I_{\mathrm{s}}$ index in the woodland site was mainly due to large positive individual PSFs in $O$. europaea, which suggests that PSFs promote the abundance of $O$. europaea in this type of forest. This idea is supported by parallel field studies in the same woodland site showing larger seedling and sapling abundance and less negative responses to declining canopy trees for $O$. europaea than for $Q$. suber, as such pointing at a conversion towards $O$. europaea-dominated systems (Ibáñez et al., 2017).

Meanwhile, a negative net-pairwise index is found when one or both species grow better in heterospecific soils. Theory predicts that reciprocal negative feedbacks, even if individual effects are weak, may promote coexistence of two competitors since each species self-limits and no one is able to monopolize a site (Bever et al. 1997). Although in our closed forest the growth of both Q. suber and $Q$. canariensis trended lower in soils from conspecifics resulting in a negative index value under a scenario of forest decline, this individual effect was much stronger for $Q$. suber. Therefore, while our results support a role of negative pairwise PSFs in mediating coexistence in declining closed forests under current feedback conditions, a decrease in the relative abundance of $Q$. suber might be expected on the long term as a result of stronger self-limitation. 
The study of net-pairwise PSFs has been strongly encouraged as a necessary tool to understand the role of PSFs for community dynamics (Kulmatiski and Kardol 2008, Brandt et al. 2013). The relatively few studies to date that have examined net-pairwise feedback dynamics have found both negative and positive interaction coefficients (e.g., Shannon et al. 2012, Smith and Reynolds 2012, Bauer et al. 2015, Kuebbing et al. 2015, Heinze et al. 2016), suggesting that the role of PSFs in mediating coexistence is species-specific. Our results add to this picture by illustrating that a given species can suffer from net-pairwise PSFs of contrasting direction under different environmental settings (i.e., sites differing in soil conditions and/or coexisting species). Therefore, we propose the need to go beyond the species level to understand the role of PSFs for community dynamics.

\section{Conclusions}

This study contributes to advance our understanding of PSFs in forests, and particularly in those subjected to disturbances associated with global change such as the invasion of soil pathogens. Although the extrapolation of PSF outcomes from the greenhouse to the field must be done with caution (e.g., Kulmatiski and Kardol 2008, Heinze et al. 2016), our results support a role of PSF in the dynamics of $Q$. suber forests invaded by Phytophthora cinnamomi as a mechanism that could reinforce the loss of dominance of $Q$. suber by promoting the relative performance of non-declining coexisting species. More generally, our results indicate an increase in the strength of net PSFs as natural forest systems become disturbed by global change drivers, suggesting an increasingly important role of PSFs in forest community dynamics in the near future. Finally, we strongly encourage future PSFs studies not to focus exclusively on microbial-driven PSFs and aboveground effects, but to extend the scope to explicitly consider the physico-chemical environment and to include belowground effects (i.e., root traits). By doing this, we will come closer to capture the complexity and variable nature of PSFs in plant communities.

\section{AcKNOWLEDGMEnTs}

We thank the director and technicians of the Alcornocales Natural Park for facilities and support to carry out the field work. Manuel Cantos and María del Mar Parra offered invaluable help with the in vitro germination of $O$. europaea seedlings. We are also indebted to Ana Pozuelos for lab and field assistance. This study was supported by the MICINN projects RETROBOS (CGL2011-26877) and INTERCAPA (CGL201456739-R), and European FEDER funds. J.D.B. and B.I. were supported by FPI-MICINN grants, and J.M.A. by a FPUMEC grant. P.K. acknowledges support from the Swedish Research Council (VR).

\section{Literature Cited}

Anonymous. 1992. Interpretación de análisis de suelo, foliar y agua de riego. Mundi-Prensa, Madrid, Consejo de abonado (normas básicas).
Anonymous. 2004. Plan de Ordenación de los Recursos Naturales y Plan Rector de Uso y Gestión del Parque Natural Los Alcornocales. Junta de Andalucía, Sevilla.

Aponte, C., L. V. García, and T. Marañón. 2013. Tree species effects on nutrient cycling and soil biota: a feedback mechanism favouring species coexistence. Forest Ecology and Management 309:36-46.

Aponte, C., L. V. García, I. M. Pérez-Ramos, E. Gutiérrez, and T. Marañón. 2011. Oak trees and soil interactions in Mediterranean forests: a positive feedback model. Journal of Vegetation Science 22:856-867.

Ávila, J. M., A. Gallardo, B. Ibáñez, and L. Gómez-Aparicio. 2016. Quercus suber dieback alters soil respiration and nutrient availability in Mediterranean forests. Journal of Ecology. https://doi.org/10.1111/1365-2745.12618.

Bardgett, R. D., and D. A. Wardle. 2010. Aboveground-belowground linkages biotic interactions, ecosystem processes, and global change. Oxford University Press, Oxford.

Bauer, J. T., K. M. L. Mack, and J. D. Bever. 2015. Plant-soil feedbacks as drivers of succession: evidence from remnant and restored tallgrass prairies. Ecosphere 6:article 158.

Bever, J. D. 2002. Negative feedback within a mutualism: hostspecific growth of mycorrhizal fungi reduces plant benefit. Proceedings of the Royal Society of London - Series B 269: 2595-2601.

Bever, J. D. 2003. Soil community feedback and the coexistence of competitors: conceptual frameworks and empirical tests. New Phytologist 157:465-473.

Bever, J. D., I. A. Dickie, E. Facelli, J. M. Facelli, J. Klironomos, M. Moora, M. C. Rillig, W. D. Stock, M. Tibbett, and M. Zobel. 2010. Rooting theories of plant community ecology in microbial interactions. Trends in Ecology and Evolution 25:468-478.

Bever, J. D., K. M. Westover, and J. Antonovics. 1997. Incorporating the soil community into plant population dynamics: the utility of the feedback approach. Journal of Ecology 85: 561-573.

Bezemer, T. M., C. S. Lawson, K. Hedlund, A. R. Edwards, A. J. Brooks, J. M. Igual, S. R. Mortimer, and W. H. Van der Putten. 2006. Plant species and functional group effects on abiotic and microbial soil properties and plant-soil feedback responses in two grasslands. Journal of Ecology 94:893-904.

Brady, N. C., and R. R. Weil. 2008. The nature and properties of soils, Fourteenth edition. Pearson-Prentice Hall, Upper Saddle River, New Jersey, USA.

Brandt, A. J., H. de Kroon, H. L. Reynolds, and J. H. Burns. 2013. Soil heterogeneity generated by plant-soil feedbacks has implications for species recruitment and coexistence. Journal of Ecology 101:277-286.

Brasier, C. M. 1992. Oak tree mortality in Iberia. Nature 360:539.

Bray, R. H., and L. T. Kurtz. 1945. Determination of total, organic, and available forms of phosphorus in soils. Soil Science 59:39-45.

Brinkman, E. P., W. H. Van der Putten, E. J. Bakker, and K. J. F. Verhoeven. 2010. Plant-soil feedbacks: experimental approaches, statistical analyses and ecological interpretations. Journal of Ecology 98:1063-1073.

Brundett, M., N. Bougher, T. Grove, and N. Malajczuk. 1996. Working with Mycorrhizas in forestry and agriculture. Aciar, Canberra.

Cahill, D. M., J. E. Rookes, B. A. Wilson, L. Gibson, and K. L. McDougall. 2003. Phytophthora cinnamomi and Australia's biodiversity: impacts, predictions and progress towards control. Australian Journal of Botany 56:279-310.

Camilo-Alves, C. S. P., M. I. E. da Clara, and N. A. Ribeiro. 2013. Decline of Mediterranean oak trees and its association 
with Phytophthora cinnamomi: a review. European Journal of Forest Research 132:411-432.

Casper, B. B., S. P. Bentivenga, B. Ji, J. H. Doherty, H. M. Edenborn, and D. J. Gustafson. 2008. Plant-soil feedback: testing the generality with the same grasses in serpentine and prairie soils. Ecology 89:2154-2164.

Castelli, J. P., and B. B. Casper. 2003. Intraspecific AM fungal variation contributes to plant-fungal feedback in a serpentine grassland. Ecology 84:323-336.

Comas, L. H., and D. M. Eissentat. 2009. Patterns in root trait variation among 25 co-existing North American forest species. New Phytologist 182:919-928.

Core Team, R. 2013. R: a language and environment for statistical computing. R Foundation for Statistical Computing, Vienna.

Cox, D. R., and D. Oakes. 1984. Analysis of survival data. Chapman and Hall, New York.

Dickie, I. A., R. T. Koide, and A. C. Fayish. 2001. Vesiculararbuscular mycorrhizal infection of Quercus rubra seedlings. New Phytologist 151:257-264.

Ehrenfeld, J. G., B. Ravit, and K. Elgersma. 2005. Feedback in the plant-soil system. Annual Review of Environment and Resources 30:75-115.

Eppinga, M. B., M. Rietkerk, S. C. Dekker, P. C. De Ruiter, and W. H. Van der Putten. 2006. Accumulation of local pathogens: a new hypothesis to explain exotic plant invasions. Oikos 114:168-176.

Finzi, A. C., C. D. Canham, and N. Van Bremen. 1998. Canopy tree-soil interactions within temperate forests: species effects on $\mathrm{pH}$ and cations. Ecological Applications 8:447-454.

Garcia, L. V. 2003. Controlling the false discovery rate in ecological research. Trends in Ecology and Evolution 18:553-554.

García, J. L. 1999. Características morfo-anatómicas, fisiológicas y bioquímicas de plantas jóvenes de olivo (Olea europaea L.) obtenidas in vitro en función de la fuente y concentración de nitrógeno. PhD Thesis. University of Sevilla, Spain.

García, L. V. 2004. Escaping the Bonferroni iron claw. Oikos 105:657-663.

Gómez-Aparicio, L., and C. D. Canham. 2008. Neighborhood models of the effects of invasive tree species on ecosystem processes. Ecological Monographs 78:69-86.

Gómez-Aparicio, L., B. Ibáñez, M. S. Serrano, P. De Vita, J. M. Ávila, I. M. Pérez-Ramos, L. V. García, M. E. Sánchez, and T. Marañón. 2012. Spatial patterns of soil pathogens in declining Mediterranean forests: implications for tree species regeneration. New Phytologist 194:1014-1024.

Gribko, L. S., and W. E. Jones. 1995. Test of float method of assessing northern red oak acorn condition. Tree Planter's Notes 46:143-147.

Harrison, K. A., and R. D. Bardgett. 2010. Influence of plant species and soil conditions on plant-soil feedback in mixed grassland communities. Journal of Ecology 98:384-395.

Heinze, J., M. Sitte, A. Schindhelm, J. Wright, and J. Joshi. 2016. Plant-soil feedbacks: a comparative study on the relative importance of soil feedbacks in the greenhouse versus the field. Oecologia 181:559-569.

Hendrix, F. F., and W. A. Campbell. 1973. Pythiums as plant pathogens. Annual Review of Plant Pathology 11:77-98.

Ibáñez, B., L. Gómez-Aparicio, J. M. Ávila, I. M. Pérez-Ramos, L. V. García, and T. Marañón. 2015. Impact of tree decline on spatial patterns of seedling-mycorrhiza interactions: implications for regeneration dynamics in Mediterranean forests. Forest Ecology and Management 353:1-9.

Ibáñez, B., L. Gómez-Aparicio, J. M. Ávila, I. M. Pérez-Ramos, and T. Marañón. 2017. Effects of Quercus suber decline on woody plant regeneration: potential implications for successional dynamics in Mediterranean forests. Ecosystems 20: 630-644.
Johnson, D. J., W. T. Beaulieu, J. D. Bever, and K. Clay. 2012. Conspecific negative density dependence and forest diversity. Science 336:904-907.

Kardol, P., T. M. Bezemer, and W. H. Van der Putten. 2006. Temporal variation in plant-soil feedback controls succession. Ecology Letters 9:1080-1088.

Klironomos, J. N. 2002. Feedback with soil biota contributes to plant rarity and invasiveness in communities. Nature 417: $67-70$.

Kuebbing, S. E., A. T. Classen, J. J. Call, J. A. Henning, and D. Simberloff. 2015. Plant-soil interactions promote co-occurrence of three nonnative woody shrubs. Ecology 96:2289-2299.

Kulmatiski, A., K. H. Beard, J. Stevens, and S. Cobbold. 2008. Plant-soil feedbacks: a meta-analytical review. Ecology Letters 11:980-992.

Kulmatiski, A., and P. Kardol. 2008. Getting plant-soil feedbacks out of the greenhouse: experimental and conceptual approaches. Progress in Botany 69:449-472.

Larios, L., and K. N. Suding. 2015. Competition and soil resource environment alter plant-soil feedbacks for native and exotic grasses. Annals of Botany 7:plu077.

Liu, G., G. T. Freschet, X. Pan, J. H. C. Cornelissen, Y. Li, and M. Dong. 2010. Coordinated variation in leaf and root traits across multiple spatial scales in Chinese semi-arid and arid ecosystems. New Phytologist 188:543-553.

López, B., S. Sabate, and C. A. Gracia. 2001. Vertical distribution of fine root density, length density, area index and mean diameter in a Quercus ilex forest. Tree Physiology 21:555-560.

Lovett, G. M., K. C. Weathers, M. A. Arthur, and J. C. Schultz. 2004. Nitrogen cycling in a northern hardwood forest: Do species matter? Biogeochemistry 67:289-308.

Lowe, S., M. Browne, S. Boudjelas, and M. De Poorter. 2004. 100 of the World's worst invasive alien species: a selection from the global invasive species database. IUCN, The Invasive Species Specialist Group.

Mack, K. M. L., and J. D. Bever. 2014. Coexistence and relative abundance in plant communities are determined by feedbacks when the scale of feedback and dispersal is local. Journal of Ecology 102:1195-1201.

Mangan, S. A., E. A. Herre, and J. D. Bever. 2010b. Specificity between Neotropical tree seedlings and their fungal mutualists leads to plant-soil feedback. Ecology 91:2594-2603.

Mangan, S. A., S. A. Schnitzer, E. A. Herre, K. M. L. Mack, M. C. Valencia, E. I. Sánchez, and J. D. Bever. 2010a. Negative plant-soil feedback predicts tree-species relative abundance in a tropical forest. Nature 466:752-755.

Manning, P., S. A. Morrison, M. Bonkowski, and R. D. Bargett. 2008. Nitrogen enrichment modifies plant community structure via changes to plant-soil feedback. Oecologia 157:661-673.

McCarthy-Neumann, S., and I. Ibáñez. 2013. Plant-soil feedback links negative distance dependence and light gradient partitioning during seedling establishment. Ecology 94:780-786.

McCarthy-Neumann, S., and R. K. Kobe. 2008. Tolerance of soil pathogens covaries with shade tolerance across species of tropical tree seedlings. Ecology 89:1883-1892.

McCarthy-Neumann, S., and R. K. Kobe. 2010. Conspecific plant-soil feedbacks reduce survivorship and growth of tropical tree seedlings. Journal of Ecology 98:396-407.

Médail, F., and P. Quézel. 1999. Biodiversity hotspots in the Mediterranean Basin: setting global conservation priorities. Conservation Biology 13:1510-1513.

Moreira, A. C., and J. M. S. Martins. 2005. Influence of site factors on the impact of Phytophthora cinnamomi in cork oak stands in Portugal. Forest Pathology 35:145-162. 
Morillas, L., A. Gallardo, M. Portillo-Estrada, and F. Covelo. 2012. Nutritional status of Quercus suber populations under contrasting tree dieback. Forestry 85:369-378.

O'Hanlon-Manners, D. L., and P. M. Kotanen. 2004. Evidence that fungal pathogens inhibit recruitment of a shade-intolerant tree, white birch (Betula papyrifera), in understorey habitats. Oecologia 140:650-653.

Pendergast, T. H., D. J. Burke, and W. P. Carson. 2013. Belowground biotic complexity drives aboveground dynamics: a test of the soil community feedback model. New Phytologist 197:1300-1310.

Pérez-Ramos, I. M., C. Roumet, P. Cruz, A. Blanchard, P. Autran, and E. Garnier. 2012. Evidence for a "plant economics spectrum" driven by nutrient and water limitations in a Mediterranean rangeland of southern France. Journal of Ecology 100:1315-1327.

Perkins, L. B., and R. S. Nowak. 2013. Native and non-native grasses generate common types of plant-soil feedbacks by altering soil nutrients and microbial communities. Oikos 122:199-208.

Reinhart, K. O., A. A. Royo, W. H. Van der Putten, and K. Clay. 2005. Soil feedback and pathogen activity in Prunus serotina throughout its native range. Journal of Ecology 93:890-898.

Rey, P. J., J. M. Alcántara, F. Valera, A. M. Sánchez-Lafuente, J. L. Garrido, and A. J. Manzaneda. 2004. Seedling establishment in Olea europaea. Seed size and microhabitat affect growth and survival. Ecoscience 11:310-320.

Roldán-Fajardo, B. E., and J. M. Barea. 1985. Mycorrhizal dependency in the olive tree (Olea europaea L.). Pages 323326 in V. Gianinazzi-Pearson and S. Gianinazzi, editors. Physiological and genetical aspects of mycorrhizae. INRA Press, Paris.

Rutten, G., D. Prati, A. Hemp, and M. Fischer. 2016. Plantsoil feedback in East-African savanna trees. Ecology 97: 294-301.

Sánchez, M. E., P. Caetano, M. A. Romero, R. M. Navarro, and A. Trapero. 2006. Phytophthora root rot as the main factor of oak decline in southern Spain. Pages 149-154 in C. M. Brasier, T. Jung, and W. Oßwald, editors. Progress in research on phytophthora diseases of forest trees. Farnham, The Forest Authority.

Sardans, J., F. Rodà, and J. Peñuelas. 2004. Phosphorus limitation and competitive capacities of Pinus halepensis and Quercus ilex subsp. rotundifolia on different soils. Plant Ecology 174:305-317.

Scanu, B., B. T. Linaldeddu, A. Franceschini, N. Anselmi, A. Vannini, and A. M. Vettraino. 2013. Occurrence of Phytophthora cinnamomi in cork oak forest in Italy. Forest Pathology 43:340-343.

Serrano, M. S., P. Ríos, M. González, and M. E. Sánchez. 2015. Experimental minimum threshold for Phytophthora cinnamomi root disease expression on Quercus suber. Phytopathologia Mediterranea 54:461-464.

Shannon, S., S. L. Flory, and H. Reynolds. 2012. Competitive context alters plant-soil feedbakcs in an experimental woodland community. Oecologia 169:235-243.

Smith, S. E., and D. J. Read. 2008. Mycorrhizal symbiosis, Third edition. Academic Press, Cambridge, UK.

Smith, L. M., and H. L. Reynolds. 2012. Positive plant-soil feedback may drive dominance of a woodland invader, Euonymus fortunei. Plant Ecology 213:853-860.

Smith, L. M., and H. L. Reynolds. 2015. Plant-soil feedbacks shift from negative to positive with decreasing light in forest understory species. Ecology 96:2523-2532.

Sotomayor-León, E. M., and J. M. Caballero. 1990. An easy method of breaking olive stones to remove mechanical dormancy. Acta Horticulturae 206:113-116.

Sykorova, Z., K. Ineichen, A. Wiemken, and D. Redecker. 2007. The cultivation bias: different communities of arbuscular mycorrhizal fungi detected in roots from the field, from bait plants transplanted to the field, and from a greenhouse trap experiment. Mycorrhiza 18:1-14.

Teste, F. P., P. Kardol, B. L. Turner, D. A. Wardle, G. Zemunik, M. Renton, and E. Laliberté. 2017. Plant-soil feedback and the maintenance of diversity in Mediterranean-climate shrublands. Science 355:173-176.

Trouvelot, A., J. L. Kough, and V. Gianinazzi-Pearson. 1986. Measure du taux de mycorhization VA d'un systeme radiculare. Recherche de methodes d'estimation ayant une signification fonctionnelle. Pages 217-221 in V. Gianinazzi-Pearson and S. Gianinazzi, editors. Physiological and genetical aspects of mycorrhizae. INRA press, Paris.

Van der Putten, W. H., M. A. Bradford, E. P. Brinkman, T. F. J. Van de Voorde, and G. F. Veen. 2016. Where, when and how plant-soil feedback matters in a changing world. Functional Ecology 30:1109-1121.

Van der Putten, W. H., C. Van Dijk, and B. A. M. Peters. 1993. Plant-specific soil-borne diseases contribute to succession in foredune vegetation. Nature 362:53-56.

Van der Putten, W. H., et al. 2013. Plant-soil feedbacks: the past, the present and future challenges. Journal of Ecology 101:265-276.

Vierheilig, H., A. P. Coughlan, U. Wyss, and Y. Piché. 1998. Ink and vinegar, a simple staining technique for arbuscularmycorrhizal fungi. Applied and Environmental Microbiology 64:5004-5007.

Weste, G., and G. C. Marks. 1987. The biology of Phytophthora cinnamomi in Australasian forests. Annual Review of Phytopathology 25:207-229.

Wurst, S., N. Kaiser, S. Nitzsche, J. Haase, H. Auge, M. C. Rillig, and J. R. Powell. 2015. Tree diversity modifies distancedependent effects on seedling emergence but not plant-soil feedbacks of temperate trees. Ecology 96:1529-1539.

\section{SUPPORTING INFORMATION}

Additional supporting information may be found in the online version of this article at http://onlinelibrary.wiley.com/doi/ 10.1002/ecy.1864/suppinfo 